Enhancement of Knowledge and Attitude Touched to Clean and Healthy Life Behavior in Restaurant in Port Ajibata Kabupaten Toba Samosir

\author{
Enny Hasriyani 1
}

\author{
1 Politeknik Pariwisata Medan \\ Correspondence : Enny Hasriyani, Politeknik Pariwisata Medan \\ Email : ennyhas@yahoo.com \\ DOI : https://doi.org/10.36983/japm.v8i2.81
}

\begin{abstract}
The increasing of knowledge is a process of increasing one's knowledge as the result of an activity throught his/her senses to a certain object. Action is one's responses to a stimulus and food handler is some one who makes direct contact to the food and equipments, star from preparations, cleaning, processing, moving and serving. The bahaviour of healthy and clean life is a group of behaviours implemented based on one's awareness as the result of learning process that makes someone can manage his healths and participate actively in realizing social gealth. This is a descriptive analysis where the research done by observing the current. This is a descriptive analysis where the research done by observing the current problems, then the datas are analyzed. This research involves 100 respondents, they are cook and waiters that they act as food handlers in restaurants and cafes in the area of Ajibata Port. The data collections are done by distributing some questionnaires to the respondents, then the questionnaires are collected as data, and then they are analyzed. The research shows that the increasingof the food handlers' knowledges and behaviours are very important because the lack of their knowledge concerning to themselves as food handlers that give impacts to the healthy and clean life behaviours that will be implemented in restaurants or cafes as their work places
\end{abstract}

Keywords: increasing of knowledge, behaviour, food handler, healthy and clean life behavior

\title{
Peningkatan Pengetahuan dan Sikap Penjamah terhadap Perilaku Hidup Bersih dan Sehat pada Restoran di Kawasan Pelabuhan Ajibata Kabupaten Toba Samosir
}

\begin{abstract}
ABSTRAK
Peningkatan Pengetahuan adalah meningkatkan pengetahuan dari hasil yang terjadinya setelah seseorang melalui pengindraan terhadap sesuatu objek tertentu.Sedangkan sikap merupakan respon yang dilakukan seseorang terhadap suatu rangsang tertentu dan Penjamah makanan adalah orang yang secara langsung berhubungan dengan makanan, peralatan, mulai dari tahapan persiapan, pembersihan, pengolahan, pengangkutan sampai dengan penyajian. Serta perilaku
\end{abstract}


hidup bersih dan sehat adalah sekumpulan perilaku yang dipraktikan atas dasar kesadaran sebagai hasil pembelajaran, yang menjadikan seseorang mampu mandiri dibidang kesehatan dan berperan aktif dalam mewujudkan kesehatan masyarakat. Jenis penelitian ini adalah deskriptif analisis yaitu metode penelitian dengan cara mengamati masalah yang ada pada saat Ini kemudian data di analisis, yang menjadi subjek dalam penelitian ini adalah juru masak dan pramusaji sebagai penjamah makanan dibeberapa restoran dan rumah makan pada kawasan pelabuhan Ajibata, berjumlah 100 responden. Data dikumpulkan dengan memberikan kuesioner dalam bentuk angket, kemudian angket tersebut dikumpul sebagai data, lalu data tersebut dianalisis. Adapun hasil analisis menunjukan bahwa peningkatan pengetahuan dan sikap penjamah makanan sangat perlu karena masih dianggap perlu karena masih ditemukan penjamah makanan yang kurang memiliki pengetahuan tentang hal yang berhubungan dengan dirinya sebagai penjamah makanan hal ini berdampak pada perilaku hidup bersih dan sehat yang akan diaplikasikan/diterapkan di restoran maupun rumahmakan sebagai tempat bekerja.

\section{Kata kunci : peningkatan pengetahuan, sikap, penjamah makanan, perilaku hidup bersih dan sehat}

\section{PENDAHULUAN}

\section{Latar Belakang}

Tingkat kunjungan wisata semakin meningkat dari tahun ketahun nya sehingga para pelaku wisata saat ini saling berlomba untuk meningkatkan pelayanan kepada wisatawan yang berkunjung kedaerahnya, tidak terkecuali bagi para pemilik restoran dan rumah makan yang ada di sekitar objek wisata terus mencari informasi hal apa saja yang perlu di perhatikan agar lebih dapat ditingkatkan pada usaha yang digelutinya dengan tujuan muntuk meningkatkan keuntungan dari kunjungan tamu /wisatawan. Selama melakukan perjalanan sudah pasti para wisatawan akan mencari kebutuhan nya terutama untuk makan dan minum, karena hal ini merupakan kebutuhan pokok bagi manusia. Oleh karenanya setiap wisatawan akan mencari tempat makan dan minum itu pastilah tempat yang bersih, kemudian baru diikuti oleh menu dan rasa yang ada di restoran atau rumah makan tersebut.

Salah satu objek wisata yang sangat diminati oleh wisatawan baik dari mancanegara maupun domistik adalah Danau Toba, karena keindahan alam serta dari letak geografisnya Danau Toba ini dikelililingi oleh 7 kabupaten, artinya keindahan danau ini dapat dinikmati dari tujuh kabupaten, salah satunya adalah kecamatan Ajibata, dan dari kawasan ini kita bisa menyeberang ke Pulau Samosir. Pelabuhan Ajibata inilah tempat persinggahan sementara para wisatawan yang hendak meneruskan perjalanan ke Pulau Samosir. Umumnya para pengunjung sudah dapat memperhitungkan waktu dengan membuat itenary yang disesuaikan dengan jadwal kapal fery, ada 5 trip perjalanan dari pelabuhan Ajibata ke Tomok setiap harinya dengan lama perjalanan setiap tripnya \pm 40 menit. Sembari menunggu kedatangan ferry banyak aktivitas yang dapat dilakukan pengunjung, diantaranya 
menikmati makanan yang ada dikawasan pelabuhan sambil melihat pemandangan alam dipinggiran Danau Toba yang indah.

Setiap individu yang melakukan perjalanan kesuatu objek wisata tidak akan terlepas dari kebutuhan akan makanan, karena makanan merupakan sumber energy bagi tubuh manusia. Selama dalam perjalanan setiap wisatawan harus mampu memilih makanan yang sudah pasti bersih dan sehat atau dengan kata lain memilih makanan yang tidak terkontaminasi dari bakteri ataupun kuman yang lain, sehingga makanan yang masuk ke tubuh benar-benar makanan yang bersih dan sehat. Hal ini akan berdampak pada kondisi kesehatan selama berada di perjalan/objek wisata.

Dari uraian diatas, maka penulis ingin membahas tentang makanan dan minuman yang disajikan kepada wisatawan/pengunjung, dimana hal ini tidak terlepas dari proses pengolahan dimulai dari bahan dasar hingga produk tersebut disajikan kepada konsumen Untuk itu pada penelitian ini membahas tentag peningkatan pengetahun dengan melihat pada perilaku hidup bersih dan sehat dimulai dari proses hingga makanan tersebut siap disajikan kepada wisatawan sebagai pengunjung dikawasan pelabuhan Ajibata, karena para penjamah makanan lah sebagai penentu dari makanan yang disajikan itu bermutu dan sehat di suatu restoran dan rumah makan.

\section{KERANGKA KONSEP}

\section{Peningkatan Pengetahuan}

Pengetahuan secara umum dapat diartikan dari tidak tahu menjadi tahu, hal ini bisa didapat dari pendidikan formal maupun dari hal yang tidak formal seperti pengalaman. Dalam Wikipedia, pengetahuan adalah berbagai gejala yang ditemui dan diperoleh manusia melalui pengamatan akal, pengetahuan, muncul ketika seseorang menggunakan akal budinya untuk mengenali benda atau kejadian tertentu yang belum dilihat atau dirasakan sebelumnya. Misalnya ketika seseorang mencicipi memasakan yang baru dikenalnya, akan mendapatkan pengetahuan tentang bentuk, rasa, dan aroma masakan.

Menurut Notoadmodjo (2003:128), pengetahuan merupakan hasil yang terjadi setelah seseorang melakukan pengindraan terhadap sesuatu objek tertentu. Pengindraan terjadi melalui panca indera, manusia yaitu : indera penglihatan, pendengaran, penciuman, rasa dan raba. Sebagian besar pengetahuan manusia diperoleh melalui mata dan telinga. Dalam domain kognitif pengetahuan mempunyai enam tingkat yaitu : Pengetahuan yang dicakup di dalam domain kognitif mempunyai yakni:

1. Tahun (know).

Tahu diartikan sebagai mengingat suatu materi yang telah dipelajari sebelumnya termasuk ke dalam pengetahuan tingkat ini adalah mengingat kembali (recall) terhadap suatu yang spesifik dari seluruh bahan yang di pelajari atau rangsangan yang telah diterima. Oleh sebab itu "tahu" ini adalah merupakan tingkat pengetahuan yang paling rendah. Kata kerja untuk mengukur bahwa orang tahu tentang apa yang di pelajari antara lain : menyebutkan, menguraikan, mendefenisikan, menyatakan, dan sebagainya.

2. Memahami (comprehension)

Memahami diartikan sebagai suatu kemampuan menjelaskan secara benar tentang objek yang diketahui, dan dapat menginterprestasikan materi tersebut secara benar.

3. Aplikasi (application)

Aplikasi diartikan sebagai kemampuan untuk menggunakan materi yang telah di pelajari pada situasi atau kondisi real (sebenarnya). Aplikasi disini dapat 
diartikan aplikasi atau penggunaan hokum II, rumus, metode, prinsip, dan sebagai berikutnya, dalam konteks atau kondisi atau situasi yang lain.

4. Analisis (analysis)

Analisis atau analisa adalah suatu kemampuan untuk menjabarkan materi atau suatu objek ke dalam komponenkomponen, tetapi masih di dalam suatu struktur organisasi tersebut, dan masih ada kaitannya satu sama lain. Kemampuan analisis ini dapat dilihat dari penggunaan kata-kata kerja : dapat menggambarkan (membuat bagan), membedakan, memisahkan, mengelompokkan, dan sebagainya.

5. Sintesis (synthesis)

Sintesis menunjuk kepada suatu kemampuan untuk melakukan atau menghubungkan bagian-bagian di dalam suatu bentuk atau keseluruhan yang baru. Dengan kata lain sintesis itu suatu kemampuan untuk menyusun, formulasi baru dari formulasi-formulasi yang ada.

6. Evaluasi (evaluation)

Evaluasi ini berkaitan dengan kemampuan untuk melakukan justifikasi atau penilaian terhadap suatu materi atau objek. Penilaian-penilaian itu berdasarkan suatu criteria yang ditentukan sendiri, atau menggunakan kriteria-kriteria yang telah ada.

\section{Sikap}

Secara umum sikap merupakan respon yang dilakukan seseorang terhadap suatu stimulus .Menurut Newcomb (dalam Notoatmodjo, 2003:131), sikap merupakan kesiapan atau kesediaan untuk bertindak. Ada tiga komponen dalam pembentukan sikap secara utuh seperti yang dijelaskan oleh Allport ( dalam Notoatmodjo, 2003:131).yaitu

1. Kepercayaan,

2. Kehidupan emosional
Dikutip dari www.dictio.id bahwa sikap berhubungan dengan tabiat tingkah laku dalamkaitannya dengan perangsangan yang relevan. Adapun cirri-ciri dari sifat tersebut adalah :

1. Sikap itu dapat dipelajari

2. Memiliki Kestabilan

3. Personal societal significance

4. Cognity dan affecti

5. Approach avoidance directionality

Selain itu sikap juga berfungsi sebagai :

1. Sebagai alat untuk menyesuaikan diri

2. Sebagai pengatur tingkah laku

3. Mengatur pengalaman-pengalaman

4. Sebagai pernyataan kepribadian

Sikap adalah penilaian seseorang terhadap stimulus. Indikaror untuk sikap kesehatan juga sejalandengan pengetahuan kesehatan seperti diatas, yakni :

a. Sikap terhadap sakit dan penyakit

Yang dimaksud dengan sikap terhadap sakit dan penyakit adalah bagaimana penilaian seseorang terhadap gejala penyakit, penyebab penyakit, cara penularan penyakit, cara pencegahan penyakit dan sebagainya.

b. Sikap cara pemeliharaan dan cara hidup sehat

Begitu juga pada sikap cara pemeliharaan dan cara hidup sehat merupakan penilaianseseorang terhadap cara-cara memelihara dan car hidup sehat

c. Sikap terhadap kesehatan lingkungan Penilaian seseorang terhadap lingkungan dan pengaruhnya terhadap kesehatan

\section{Penjamah Makanan}

Dikutip dari enviro24wordpression, dalam Permenkes no. 1098 tentang Hygiene Rumah Makan Dan Restoran, Penjamah makanan adalah orang yang secara langsung berhubungan dengan makanan, peralatan, mulai dari tahap persiapan, pembersihan, pengolahan, pengangkutan, sampai dengan penyajian. 
Dari uraian diatas, maka yang termasuk sebagai penjamah makanan pada suatu restoran adalah seorang jurumasak dan pramusaji.Dalam Kamus Besar Bahasa Indonesia (2002:113) juru masak adalah seseorang yang bertugas mengolah makanan di dapur sedangkan menurut Chris Ashton (2003:1) Pada bidang jasa boga pembagian tugas kerja di dapur sesuai dengan tugas dan tanggung jawab masing-masing juru masak yang dibagi sesuai dengan jabatan dan tanggun jawab sebagai berikut :

a. Executive Chef

Bertanggung jawab atas seluruh pengoperasian dan penyiapan makanan baik di dapur maupun di pantry.

b. Second Executive Chef

Menbantu executive chef dalam pengoperasian dan penyiapan makanan.

c. Sous Chef

Bertanggung jawab dalam pengawasasn di seluruh wilayah dapur dan tempat penyiapan makanan yang terdapat di dapur.

\section{d. Chef de Partie}

Bertanggung jawab atas pengoperasian kerja di setiap seksi yang ad di dapur.

Sedangkan Pramusaji menurut Marsum (1995:90) waiter atau waitress ialah seseorang yang menyajikan makanan dan minuman. Hal tersebut sesuai dengan tugas utamanya menurut Ardjuno (2002:11) adalah melayani tamu. Disamping itu pramusaji juga bertanggung jawab pada persiapan restoran sebelum restoran di buka, yaitu melengkapi semua perlengkapan yang akan digunakan dalam operasional, seperti chinawares, silverwares, glasswares, serta menjaga kebersihan lingkungan kerja, keamanan dan keselamatan kerja. Sebagai seorang yang berhubungan langsung dengan tamu dalam menjalankan tugasnya sorang waiter (pramusaji) di tuntut memiliki persyaratan sebagai berikut :
1. Ramah tamah, sikap ramah tamah dan sopan santun merupakan hal yang harus selalu di perlihatkan setiap saat.

2. Penampilan pribadi, merupakan hal yang sangat penting dan harus diketahui serta dilaksanakan oleh setiap petugas yang berhubungan langsung dengan tamu. Hal itu sangat besar pengaruhnya dalam usaha memberikan kesan pertama yang baik kepada setiap tamu di restoran.

\section{Perilaku Bersih dan Sehat}

Dalam kehidupan sehari-hari sangat diperlukan tindakan hidup bersih dan sehat, dimana hal ini sebenarnya sangat berkitan erat dengan promosi kesehatan yaitu meningkatkan derajat kesehatan masyarakat. Perilaku hidup bersih dan sehat (PHBS) ini lebih menerapkan pada individu, menurut Dewi dan Nunung (2018:201) PHBS adalah sekumpulan perilaku yang di praktikan atau dasa kesadaran sebagai hasil pembelajaran, yang menjadikan seseorang, keluarga, kelompok atau masyarakat mampu menolong dirinya sendiri (mandiri) di bidang kesehatan dan berperan aktif dalam mewujudkan kesehatan masyarakat.

Dikutip dari promkes.kemkesgi.id tujuan utama dari perilaku hidup bersih dan sehat adalah meningkatkan kualitas kesehatan melalui proses penyadartahuan yang menjadi awal dari kontribusi tiap-tiap individu dalam menjalani kehidupan seharihari yang bersih dan sehat. Selain hal tersebut diatas, perilaku hidup bersih dan sehat bermanfaat untuk menciptakan masyarakat yang kesehatan dan memiliki bekal pengetahuan dan kesadaran untuk menjalani perilaku hidup yang menjaga kebersihan dan memenuhi standar kesehatan.

Salah satu dari lima tatanan perilaku hidup bersih dan sehat adalah perilaku hidup bersih dan seht ditempat kerja yaitu untuk memberdayakan para pekerja agar tahu dan mau untuk melakukan perilaku hidup bersih 
dan sehat serta berperan dalam menciptakan tempat kerja yang sehat.

Secara umum perilaku identik dengan tingkah laku artinya dapat terlihat oleh mata tindakan-tindakan atau aktivitas yang dilakukan tiap-tiap individu. Menurut Skinner (dalam Notoatmodjo, 2003:118), perilaku adalah hasil hubungan antara perangsang(stimulus) dan tanggapan (respon), ada dua respon yaitu :

1. Respondent respon atau reflextive respon yaitu respon yang ditimbulkan oleh rangsangan-rangsangan tertentu. Perangsangan semacam ini disebut elicting Stimuli, karena menimbulkan respon-respon yang relative tetap. Misal : Makanan lezat menimbulkan air liur keluar, cahaya yang kuat menimbulkan mata tertutup. Respon ini mencakup juga emosi respon ( emotional behavior). Emotional respon ini timbul karena hal yang kurang mengenakan organism yang bersangkutan. Misalnya menangis karena sedih atau sakit atau sebaliknya hal yang menyenangkan missal tertawa

2. Operant respons atau instrumental respons adalah respons yang timbul dan berkembangnya diikuti oleh perangsang semacam ini disebut reinforang stimuli atau reinforce, karena perangassanperangasngan tersebut memperkuat respons yang telah dilakukan oleh organism. Mis : Seorang anak belajar atau telah melakukan sesuatu perbuatan kemudian memperoleh hadiah, amka ia akan menjadi lebih giat belajar atau akan lebih baik lagi melakukan perbuatan tersebut.

Dalam kehidupan sehari-hari respondent respons sangat terbatas keberadaanya.Perilaku sehat, menurut Notoatmodjo (2003:121), adalah suatu respons seseorang terhadap stimulus yang berkaitan dengan sakit dan penyakit, sistim pelayanan kesehatan, makanan, serta lingkungan. Respon atau reaksi manusia, baik bersifat pasif(pengetahuan, persepsi, dan sikap) maupun bersifat aktif (tindakan nyata atau practice).

Menurut skiner dalam As'ad (2000), seorang ahli psikologi merumuskan bahwa perilaku merupakan respons atau reaksi seseorang terhadap stimulus (rangsangan dari luar) oleh karena perilaku ini terjadi melalui proses adanya stimulus terhadap organism dan kemudian organism tersebut merespon, maka teori skiner ini disebut teori "S-O-R" atau stimulus-organismerespons.Berdasarkan batasan perilaku dari skinner, maka perilaku sehat adalah respon seseorang terhadap stimulus yang berkaitan dengan sakit dan penyakit, sistem pelayanan kesehatan, makanan, dan minuman serta lingkungan.

Perilaku sehat diklasifikasikan menjadi 3 kelompok ( Notoatmodjo, 2003 )

1. Perilaku Pemeliharan Kesehatan

Adalah perilaku seseorang untuk memelihara atau menjaga kesehatan agar usaha penyembuhan bilaman sakit. Oleh sebab itu perilaku pemeliharan kesehatan ini terjadi dari 3 (tiga) aspek, yaitu :

a. Perilaku pencegahan penyakit dan penyembuhan penyakit bila sakit, serta pemulihan kesehatan bila mana telah sembuh dari penyakit.

b. Perilaku peningkatan kesehatan bagi seseorang yang dalam keadaan sehat. Perlu dijelaskan, bahwa kesehatan itu sangat dinamis dan relative, maka dari itu orang yang sehat pun perlu diupayakan agar mencapai tingkat kesehatan yang seoptimal mungkin.

c. Perilaku gizi (makanan dan minuman) dapat memelihara dan meningkatkan kesehatan seseorang, tetapi sebaliknya makanan dan minuman dapat menjadi penyebab menurunya kesehatan seseorang bahkan dapat mendatangkan penyakit. 
2. Perilaku Pencapaian Pengobatan

Perilaku ini adalah menyangkut upaya sesorang pada saat menderita atau kecelakaan.Perilaku ini dimulai dari mengobati sendiri sampai mencari pengobatan keluar.

3. Perilaku Kesehatan Lingkungan

Adalah bagaimana seseorang mengelola lingkungannya sehingga tidak mengganggu kesehatannya sendiri, keluarga atau masyarakat.

kecamatan Ajibata

Menurut Pangihutan

(2018:2)

Kecamatan Ajibata merupakan salah satu kecamatan di kabupaten toba samosir dengan luas wilayah $72,8 \mathrm{~km} 2$. Dibagi menjadi 10 wilayah terdiri dari 9 desa dan 1 kelurahan selain itu kecamatan Ajibata memiliki 32 dusun, dimana desa perdamean Ajibata merupakan desa yang paling banyak memiliki dusun dan desa motung merupakan desa yang paling sedikit dusunnya. Sedangkan untuk luas wilayah, desa perdamean sibisa merupakan desa dengan wilayah terluas. Yaitu 16,0 km2 atau 21,98\% dari total kecamatan Ajibata dan desa yang memiliki wilayah terkecil sekitar $3 \mathrm{~km} 2$ atau $4,12 \%$ adalah desa persaoran ajibata.

Umumnya sarana perdagangan disuatu daerah berhubungan dengan perekonomiannya sehingga dapat di diskripsikan apakah daerah tersebut maju tidak perekonomiannya, untuk kecamatan Ajibata terdapat 1 jenis pasar yaitu pasar dengan bangunan permanen, 1 unit desa pardamean Ajibata, sedangkan untuk took kelontong sebanyak 170 unit dan warung makan minum sebanyak 167 unit.

\section{METODOLOGI}

\section{Rancangan Penelitian}

Pada Penelitian ini menggunakan tipe desain deskriptif yang ditujukan untuk memperoleh gambaran kenyataan yang sudah berlangsung kepada subjek.

Populasi dan Sampel

Menurut Arikunto (2003:111) populasi adalah keseluruhan dari obyek penelitian.Dalam penelitian ini populasinya adalah para Penjamah makanan yang bekerja direstoran atau rumah makan di kawasan pelabuhan Ajibata.

\section{Teknik Pengumpulan Data}

Metode pengumpulan data yang digunakan dalam penelitian ini dengan menyebarkan kuesioner dalam bentuk angket.

\section{Analisa Data}

Analisa yang menggambarkan pengatuh antara variabel dengan menggunakan kuesioner kemudian hasil akan dideskripsikan

\section{HASIL DAN PEMBAHASAN}

\section{Hasil Penelitian \\ Lokasi Penelitian}

Penelitian dilakukan pada restoran dan rumah makan, tepatnya di kawasan Pelabuhan Ajbata.

\section{Restoran dan Rumah makan}

Menurut Marsum (2005:7) Restoran adalah suatu tempat atau bangunan yang dikomersilkan untuk umum dan memberikan pelayanan dengan baik kepada semua tamu baik berupa makanan maupun minuman, sedangkan rumah makan juga mempunyai arti kedai atau tempat makan (Menjual Makanan).

Dilihat dari uraian diatas, restoran dan rumah makan mempunyai persamaan yaitu suatu bangunan yang diperuntukan kepada khalayak memenuhi kebutuhan akan makan dan minum, secara makna mungkin sama tetapi yang membedakan nya mungkin dari jenis dan cara penyajian/pelayanan yang diberikan oleh restoran dan rumah makan tersebut. 


\section{Gambaran Umum Penjamah Makanan}

Dikutip dari enviro24wordpression, dalam Permenkes no. 1098 tentang Hygiene Rumah Makan Dan Restoran, Penjamah makanan adalah orang yang secara langsung berhubungan dengan makanan, peralatan, mulai dari tahap persiapan, pembersihan, pengolahan, pengangkutan, sampai dengan penyajian.

Dari uraian diatas, maka yang termasuk sebagai penjamah makanan pada suatu restoran adalah seorang jurumasak dan pramusaji.Dalam Kamus Besar Bahasa Indonesia (2002:113) juru masak adalah seseorang yang bertugas mengolah makanan di dapur, sedangkan pramusaji adalah orang yang menyajikan atau melayani tamu.

\section{Karekteristik Subjek Penelitian}

Pada Penelitian ini yang menjadi subjek adalah para Penjamah makanan yang bekerja pada restoran maupun rumah makan dikawasan pelabuhan Ajibata yang berjumlah 100 orang. Adapun karasteristik Subjek penelitian di distribusikan pada jenis kelamin,umur,yang dapat pada tabel berikut ini :

\section{Tabel Distribusi Pengungsi Berdasarkan Jenis Kelamin}

\begin{tabular}{|l|c|c|}
\hline \multicolumn{1}{|c|}{ Jenis Kelamin } & $\begin{array}{c}\text { Jumlah ( } \\
\text { Orang ) }\end{array}$ & Jumlah ( \% ) \\
\hline Pria & 45 & 45 \\
\hline Wanita & 55 & 55 \\
\hline Jumlah & 100 Orang & $100 \%$ \\
\hline
\end{tabular}

Sumber : Data diolah, 2019

Berdasarkan Tabel dapat dilihat yang menjadi subjek pada penelitian ini 45 orang berjenis kelamin pria dan 55 orang berjenis kelamin wanita. Hal ini terlihat wanita lebih dominan dibanding pria karena wanita di restoran atau rumah makan yang umumnya mengolah makanan.
Tabel Distribusi Pengungsi Berdasarkan Usia

\begin{tabular}{|c|c|c|}
\hline $\begin{array}{c}\text { Umur } \\
\text { (Tahun) }\end{array}$ & $\begin{array}{c}\text { Jumlah } \\
\text { (Orang) }\end{array}$ & Jumlah (\%) \\
\hline $25-35$ & 30 & 30 \\
\hline $36-45$ & 50 & 50 \\
\hline $46-50$ & 20 & 20 \\
\hline Jumlah & 100 Orang & $100 \%$ \\
\hline
\end{tabular}

Sumber : Data diolah, 2019

Berdasarkan Tabel dapat diketahui bahwa tingkat usia yang di ambil menjadi subjek di sebar pada kelompok usia artinya tingkat kematangan emosi sudah stabil dan sebaran jumlah yang dominan pada usia 50 tahun yaitu sebanyak 50 orang, dimana pada kelompok usia ini umumnya sebagai juru masak.

\section{Hasil Analisis}

Pada suatu objek wisata usaha kuliner sudah pasti menjadi sasaran utama pengunjung, karena makanan dan minuman adalah kebutuhan bagi tubuh manusia. Oleh karenannya yang menjadi ujung tombak pada kualitas makanan yang disjikan berada ditangan para penjamah makanan yang bekerja di sebuah restoran atau rumah makan. Untuk hal tersebut diatas dianggap penting peningkatan pengetahuan agar dapat berperiku bersih dan sehat pada saat bekerja dan pada penelitian ini dapat dilihat pada tabel yang ada dibawah ini :

\section{Hasil analisis peningkatan dan sikap}

Tabel tanggapan respondententang memahami fungsi alat pelindung diri $\mathbf{n}=\mathbf{1 0 0}$

\begin{tabular}{|l|c|c|}
\hline Pernyataan & $\begin{array}{c}\text { Jumlah } \\
\text { (Orang) }\end{array}$ & Jumlah (\%) \\
\hline Ya & 85 & 85 \\
\hline Tidak & 15 & 15 \\
\hline Jumlah & 100 Orang & $100 \%$ \\
\hline
\end{tabular}

Sumber : Data diolah, 2019 
Berdasarkan Tabel diatas, terlihat 85 orang reponden menjawab ya dan 15 orang menjawab tidak dari jawaban di atas dapat di analisis bahwa Sudah dominan penjamah makanan yang sebagai responden memahami fungsi Alat Pelindung Diri , namun demikian masih ada penjamah makanan yang tidak memahami fungsi dari Alat pelindung Diri bila digunakan pada saat operasional berlangsung, hal ini merdampak pada kurang safety penjamah makanan sehingga berhubungan dengan kenyamanan pada saat operasional berlangsung.

Tabel tanggapan responden terhadap hubungan kebersihan diri

Dengan makanan dan minuman yang akan disajikan

$\mathbf{n}=\mathbf{1 0 0}$

\begin{tabular}{|l|c|c|}
\hline \multicolumn{1}{|c|}{ Pernyataan } & $\begin{array}{c}\text { Jumlah ( } \\
\text { Orang ) }\end{array}$ & Jumlah ( \% ) \\
\hline Ya & 100 & 100 \\
\hline Tidak & - & - \\
\hline Jumlah & 100 Orang & 100 \\
\hline
\end{tabular}

Sumber : Data diolah, 2019

Dari tabel di atas terlihat 100 orang responden menjawab Ya, Dari jawaban tersebut diatas, terlihat bahwa seluruh penjamah makanan sudah melakukan dengan baik kebersihan dirinya terlebih dahulu dengan demikian bahan makanan yang akan diproses nantinya tidak akan terkontaminasi dari penjamah makanan.

Tabel tanggapan responden terhadap kebersihan perlengkapan kerja pada Saat sebelum dan sesudah digunakan

$\mathrm{n}=\mathbf{1 0 0}$

\begin{tabular}{|l|c|c|}
\hline \multicolumn{1}{|c|}{ Pernyataan } & $\begin{array}{c}\text { Jumlah } \\
\text { (Orang) }\end{array}$ & Jumlah (\%) \\
\hline Ya & 100 & 100 \\
\hline Tidak & - & - \\
\hline Jumlah & 100 Orang & 100 \\
\hline
\end{tabular}

Sumber : Data diolah, 2019

Dari tabel diatas, terlihat 100 responden menjawab Ya, dari jawaban diatas sebagai penjamah makanan selalu memperhatikan kondisi peralatan kerja yang digunakan, artinya para penjamah makanan ini sudah memahami bahwa peralatan kerja itu harus benar-benar diperhatiakan kebersihannya. Karena dari perlengkapan/peralatan kerja bisa mempengaruhi kualitas produk yang mereka hasilkan, selain itu bila peralatan terjaga maka tanpa disadari para penjamah makanan ini telah juga merawat peralatan kerjanya.

Tabel Tanggapan Responden Tentang Menjaga Kebersihan Diri Selama Operasional Berlangsung $\mathbf{n}=\mathbf{1 0 0}$

\begin{tabular}{|l|c|c|}
\hline \multicolumn{1}{|c|}{ Pernyataan } & $\begin{array}{c}\text { Jumlah } \\
\text { (Orang) }\end{array}$ & Jumlah (\%) \\
\hline Ya & 100 & 100 \\
\hline Tidak & - & - \\
\hline Jumlah & 100 Orang & 100 \\
\hline
\end{tabular}

Sumber : Data diolah, 2019

Dari tabel 4.4 diatas, terlihat bahwa seluruh responden menjawab Ya, hal ini sangat dipahami oleh penjamah makanan karena dengan menjaga kebersihan diri mereka, maka tamu tidak enggan masuk ke restoran/rumah makan.

Tabel tanggapan responden tentang setiap penjamah makanan

Menjaga kebersihan area kerja $\mathbf{n}=\mathbf{1 0 0}$

\begin{tabular}{|l|c|c|}
\hline Pernyataan & $\begin{array}{c}\text { Jumlah } \\
\text { (Orang) }\end{array}$ & Jumlah ( \% ) \\
\hline Ya & 80 & 80 \\
\hline Tidak & 20 & 20 \\
\hline Jumlah & 100 Orang & 100 \\
\hline
\end{tabular}

Sumber : Data diolah, 2019

Dari tabel di atas terlihat bahwa $80 \%$ responden menjawab Ya, dan $20 \%$ menjawab tidak, artinya sebagian besar penjamah makan ini sudah memperhatikan 
kebersihan area kerjanya, walau demikian masih ditemukan penjamah makanan kurang memperhatikan kebersihan area kerja karena ketika tamu meninggalkan tempat, mereka tidak langsung membersihkan meja tersebut, hal ini berdampak pada citra restoran dan rumah makan tersebut.

Tabel Tanggapan Responden tentang Penjamah Makanan yang Terserang Flu tidak Diperkenankan Bekerja

\begin{tabular}{|l|c|c|}
\hline \multicolumn{1}{|c}{ Pernyataan } & $\begin{array}{c}\text { Jumlah } \\
\text { (Orang) }\end{array}$ & Jumlah (\%) \\
\hline Ya & 85 & 85 \\
\hline Tidak & 15 & 15 \\
\hline Jumlah & 100 Orang & 100 \\
\hline
\end{tabular}

Sumber : Data diolah, 2019

Dari tabel diatas, 85 orang responden menjawab Ya, dan 15 responden menjawaba tidak hal ini dapat dianalisis bahwa mereka kurang paham bila flu itu akan sangat mengganggu pekerjaan selain pekerja karena hidung tersumbat dan ada juga yang meler sehingga pekerja tersebut merasa susah bernafas dan kepala pusing bahkan sampai badan terasa meriang selain itu, tamu juga terganggu karena tamu tidak merasa nyaman dan akan merasa enggan jika dilayani oleh pekerja yang sedang flu, karena bisa tertular dan makanan serta minuman yang disajikan pun dapat terkontaminasi oleh virus bila penjamah makanan masih ada yang bekerja pada saat terserang flu .

Tabel Tanggapan Responden terhadap Terjaminya Kebersihan Makanan Mulai dari Proses Sampai Tersaji

\begin{tabular}{|l|c|c|}
\hline \multicolumn{1}{|c|}{ Pernyataan } & $\begin{array}{c}\text { Jumlah } \\
\text { (Orang) }\end{array}$ & Jumlah (\%) \\
\hline Ya & 100 & 100 \\
\hline Tidak & - & - \\
\hline Jumlah & 100 Orang & 100 \\
\hline
\end{tabular}

Sumber : Data diolah, 2019
Dari tabel di atas 100 responden menjawab Ya dari jawaban tersebut terlihat bahwa seluruh Penjamah Makanan sudah merasa yakin bahwa makanan yang diolah terjamin kebersihannya sampai ke konsumen pada saat disajikan, dengan demikian tamu tidak merasa ragu terhadap kualitas makanan yang dipesankan/disajikan.

Tabel Tanggapan Responden tentang Selalu Membersihkan Tangan Dengan Sabun dan dikeringkan Sebelum dan Sesudah Digunakan $\mathrm{n}=\mathbf{1 0 0}$

\begin{tabular}{|l|c|c|}
\hline Pernyataan & $\begin{array}{c}\text { Jumlah } \\
\text { (Orang) }\end{array}$ & Jumlah (\%) \\
\hline Ya & 95 & 95 \\
\hline Tidak & 5 & 5 \\
\hline Jumlah & 100 Orang & 100 \\
\hline
\end{tabular}

Sumber : Data diolah, 2019

Dari tabel diatas 95 orang responden menjawab Ya, artinya hampir seluruh penjamah makanan sudah melakukan mencuci tangan sesudah dan sebelum digunakan pakai sabun kemudian dikeringkan, hal ini dilakukan penjamah makanan karena tangan yang akan dipakai apabila dalam keadaan kotor akan membuat makanan tersebut terkontaminasi, namun demikian masih ada juga yang hanya mencuci dengan air tanpa memakai sabun dan tidak dikeringkan, kondisi ini bisa saja masih ada kuman yang menempel ditangan dan terkontaminasi pada bahan dasar dan produk.

Tabel Tanggapan Responden tentang seluruh Penjamah Makanan Tidak Merokok saat Operasional Berlangsung $\mathbf{n}=\mathbf{1 0 0}$

\begin{tabular}{|l|c|c|}
\hline \multicolumn{1}{|c|}{ Pernyataan } & $\begin{array}{c}\text { Jumlah } \\
\text { (Orang) }\end{array}$ & Jumlah (\%) \\
\hline Ya & 100 & 100 \\
\hline Tidak & - & - \\
\hline Jumlah & 100 Orang & 100 \\
\hline
\end{tabular}

Sumber : Data diolah, 2019 
Dari tabel diatas 100 orang responden menjawab Ya, artinya seluruh penjamah makanan sudah menyadari tidak merokok selama operasional berlangsung, kondisi ini sudah sangat baik bagi pekerja dan restoran /rumah makan, kondisi ini secara langsung berdampak pada kesehatan penjamah makanan itu sendiri juga berdampak pada kesehatan lingkungan.

Tabel Tanggapan Responden tentang

Seluruh Peralatan Makanan yang Digunakan Tamu dalam Kondisi Bersih dan Kering $\mathbf{n}=\mathbf{1 0 0}$

\begin{tabular}{|l|c|c|}
\hline \multicolumn{1}{|c|}{ Pernyataan } & $\begin{array}{c}\text { Jumlah ( } \\
\text { Orang ) }\end{array}$ & Jumlah ( \% ) \\
\hline Ya & 100 & 100 \\
\hline Tidak & - & - \\
\hline Jumlah & 100 Orang & 100 \\
\hline
\end{tabular}

Sumber : Data diolah, 2019

Dari tabel diatas 100 responden menjawab Ya, artinya seluruh peralatan yang akan digunakan untuk tamu sudah benar-benar bersih dan dalam kondisi kering, artinya sudah dipastikan tidak aka ada bakteri yang ditimbulkan dari air.

Tabel Tanggapan Responden tentang

Selesai Pencucian Seluruh Peralatan

Disimpan pada Tempat /Rak yang Tertutup

$\mathrm{n}=\mathbf{1 0 0}$

\begin{tabular}{|l|c|c|}
\hline Pernyataan & $\begin{array}{c}\text { Jumlah ( } \\
\text { Orang ) }\end{array}$ & Jumlah ( \% ) \\
\hline Ya & 70 & 70 \\
\hline Tidak & 30 & 30 \\
\hline Jumlah & 100 Orang & 100 \\
\hline
\end{tabular}

Sumber : Data diolah, 2019

Dari tabel di atas terlihat 70 responden menjawab Ya bahwa kecenderungan penjamah makanan menyimpan peralatan yang sudah dicuci disimpan dalam tempat atau rak yang tertutup, sedangkan 30 responden tidak menyimpan pada rak tertutup karena memang tidak adanya fasilitas rak yang tertutup sehingga mereka hanya menggunakan fasilitas yang tersedia saja.

Tabel tanggapan responden tentang sisa makanan dibuang

Pada tempat sampah yang tertutup $\mathbf{n}=\mathbf{1 0 0}$

\begin{tabular}{|l|c|c|}
\hline Pernyataan & $\begin{array}{c}\text { Jumlah ( } \\
\text { Orang ) }\end{array}$ & Jumlah ( \% ) \\
\hline Ya & 80 & 80 \\
\hline Tidak & 20 & 20 \\
\hline Jumlah & 100 Orang & 100 \\
\hline
\end{tabular}

Sumber : Data diolah, 2019

Dari tabel diatas, 80 orang responden menjawab Ya dan masih di temukan 20 orang tidak ,dari data di atas dapat di analisis bahwa sebagian besar responden telah membuang sisa makanan pada tempat sampah yang tertutup, sedangkan 20 responden hanya membuang sampah dengan wadah plastic saja kemudian membuang ke tempat sampah sehingga banyak lalat berkumpul di sampah tersebut.

\section{PENUTUP}

\section{Simpulan}

Dari hasil analisis pada bab sebelumnya, dapat di simpulkan bahwa :

1. Peningkatan Pengetahuan Penjamah makanan pada Restoran dan Rumah makan di Kawasan Ajibata perlu ditingkatkan lagi, terlihat dari masih ada penjamah makanan yang tidak memahami fungsi dari Alat Pelindung Diri, karena bila seseorang pekerja tidak memahami fungsi Alat Pelindung Diri, maka pekerja tersebut tidak akan menggunakan Alat Pelindung Diri atas kesadaran diri selama operasional dan akan fatal akibatnya ketika terjadi kecelakaan akibat kerja., Selain hal tersebut diatas, masih ada penjamah makanan yang kurang 
memperhatikan lingkungan kerjannya seperti tidak langsung membersihkan meja pada saat tamu telah selesai makan dan meninggalkan tempat sehingga berdampak pada area kerja yang terlihat kotor, serta masih ditemukan nya penjamah makanan yang terserang flu tetapi tetap bekerja, hal ini bisa menularkan penyakit kepada pekerja lain maupun kepada tamu, serta makanan dan minuman pun dapat terkontaminasi virus.

2. Perilaku Bersih dan Sehat penjamah makanan sudah cukup baik, artinya para penjamah makanan ini sudah menerapkan perilaku sehat pada saat oprasional berlangsung, kalaupun ada beberapa hal seperti tidak menyimpan peralatan yang telah dicuci ditempat/rak yang tertutup dan tidak membuang sisa makanan tamu ditempat sampah yang tertutup karena fasilitas tidak tersedia di tempat kerja mereka.

\section{Saran}

Dari kesimpulan tersebut diatas diharapkan agar ;

1. Agar para penjamah makanan untuk mau membuka diri dalam hal meningkatkan pengetahuan yang bermanfaat dengan cara banyak membaca atau melihat dari media sosial terutama yang berhubungan dengan dunia kerja sebagai penjamah makanan seperti pengetahuan tentang manfaat tentang Alat Pelindung Diri, serta tentang lingkungan kerja dan dampak penyakit apa saja yang dapat menular kepada orang disekitar kita serta menjadikan makanan dan minuman yang ada menjadi makan dan minuman tidak sehat.

2. Diharapkan para penjamah makanan mempertahankan perilaku yang sudah baik dan kepada pemilik restoran dan rumah makan agar menyediakan fasilitas tempat penyimpanan peralatan yang sudah dicuci pada rak yang tertutup dan tempat tempat sampah yang tertutup sesuai standar kesehatan.

\section{DAFTAR PUSTAKA}

Arikunto, 2003, Manajemen Penelitian, PT. Rineka Cipta, Jakarta.

Kamus Besar Bahasa Indonesia Edisi Ketiga , 2002, Departemen Pendidikan Nasional, Balai Pustaka, Jakarta.

Marsum, 2005, Restoran dan Segala Permasalahannya, CV.Andi Offset, Yogyakarta

Notoatmodjo Soekidjo, Ilmu Kesehatan Masyarakat, 2003, Rineka Cipta, Jakarta.

Putri Dewi dan Rachmawati Nunung, Antropologi Kesehatan,2018, Pustaka Baru Pers, Jogjakarta

Pangihutan Nadeak, 2018, Kecamatan Ajibata Dalam Angka 2018, CV.Rilis, Tobasa

Permenkes no 1098

enviro24wordpression

\section{UCAPAN TERIMA KASIH}

Penulis mengucapkan terima kasih kepada Bapak Direktur Politeknik Pariwisata Medan atas bantuan dan dukungannya sehingga publikasi hasil penelitian ini dapat diterbitkan.

\section{Biodata :}

Enny Hasriyani, S.Psi, M.Kes adalah Dosen dengan jabatan Lektor Kepala pada Politeknik Pariwisata Medan. 